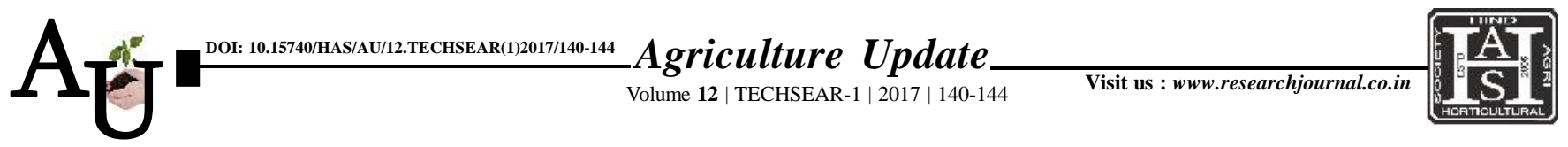

口 e ISSN-0976-6847

\title{
Research article: Economics of practicing integrated weed management in irrigated greengram (Vigna radiata L.)
}

Article Chronicle: Received : 11.07.2017;

Accepted : 26.07.2017

KeY Words : Greengram, PEPendimethalin, EPOEQuizalofop-ethyl, Imazethapyr, Rotary weeding, Hand weeding
Author for correspondence :

\section{T. MUTHURAM}

Agricultural College and Research Institute, Tamil Nadu Agricultural

University, KILLIKULAM (T.N.) INDIA

See end of the article for authors' affiliations

\section{T. MUTHURAM, R. KRISHNAN AND G. MURUGAN}

SUMMARY : A field investigation was carried out during Rabi seasons of 2014 at Agricultural College and Research Institute, Tamil Nadu Agricultural University, Killikulamto study the Integrated weed management in greengram(Vigna radiata L.) Co $6(\mathrm{Gg})$ under irrigated condition. The treatments consisted at three different spacing viz., $(25 \times 25 \mathrm{~cm}, 30 \times 30 \mathrm{~cm}$ and $30 \times 10 \mathrm{~cm})$ weed free plot and an weeded control. The results revolved that integration of chemical, mechanical and cultural methods of weed control markedly influence the yield and economics of green gram. The analysis of grain yield data revealed that pre-emergence application of pendimethalin @ $1.0 \mathrm{~kg} \mathrm{a}^{\mathrm{i}}$. ha ${ }^{-1}$ (3 DAS) followed by early post-emergence application of quizalofop-ethyl and imazethapyr @ $50 \mathrm{~g}$ a.i. ha ${ }^{-1}$ (15 DAS) in $30 \times$ $30 \mathrm{~cm}$ higher grain yield of $1006 \mathrm{~kg} \mathrm{ha}^{-1}$ and highest benefit cost ratio, respectively.

How to cite this article : Muthuram, T., Krishnan, R. and Murugan, G. (2017). Economics of practicing integrated weed management in irrigated greengram (Vigna radiata L.) Karnataka. Agric. Update, 12(TECHSEAR1) : 140-144; DOI: 10.15740/HAS/AU/12.TECHSEAR(1)2017/140-144. 